\title{
Importance of Coding Education and Robotic Applications for Achieving 21st-Century Skills in North Cyprus
}

\author{
https://doi.org/10.3991/ijet.v12i01.6097 \\ Sezer Kanbul \\ Near East University, Nicosia, North Cyprus \\ sezer.kanbul@neu.edu.tr \\ Huseyin Uzunboylu \\ Near East University, Nicosia, North Cyprus \\ huseyin.uzunboylu@neu.edu.tr
}

\begin{abstract}
Coding education and robotic applications are integrated or being integrated into education system for students at early ages all around the world. Aim of this study is to reveal the importance of coding education and robotic applications for achieving 21 st-century skills in North Cyprus. This study is a descriptive study based on literature review. The obtained data were evaluated by the researcher to reveal the current case with a descriptive approach. It is really important for students to receive education on coding and robotics applications in order to be able to acquire 21 st-century skills, develop, produce and achieve "Informatics Island" vision of North Cyprus. In this research, it is observed that importance given to coding education and robotic applications in North Cyprus is insufficient. It is also revealed that there are effective robotic studies as a result of institutional efforts by universities. However, there is no attempt to integrate coding education into primary, secondary and university education programs and there is a little number of academic research related with coding education and robotic applications. It is expected that this study will be a guide for academicians who would like to conduct research in this field, provide information about the present condition and set an example.
\end{abstract}

Keywords - 21st-century skills, coding education, computational thinking, robotic applications.

\section{Introduction}

As a result of the incredible development of the internet, wireless communication tools and mobile technologies take place in every level of education $[20,26,27]$. Based on this development, smart systems and robotic applications which make human life easier have become more integrated into our lives [24]. In many countries, there are software projects in this field constituted by support from companies, governments and universities. However, companies in North Cyprus report that there is 
Paper-Importance of Coding Education and Robotic Applications For Achieving 21st-Century Skills in North Cyprus

insufficient number of good software developers and there are no such attempts enough.

Therefore, there is a need for students to acquire skills for producing solutions for problems, develop new ideas in an area of profession, human sciences and social sciences by using computer sciences and applications beginning from early childhood education [31]. Recently, it is frequently mentioned that students need to receive coding education at early ages all around the world [4] since basic skills in which 21 stcentury individuals must have could be acquired by teaching coding and computational thinking skills [13, 34, 29, 32]. 21st-century skills are shown in Figure1 [30].

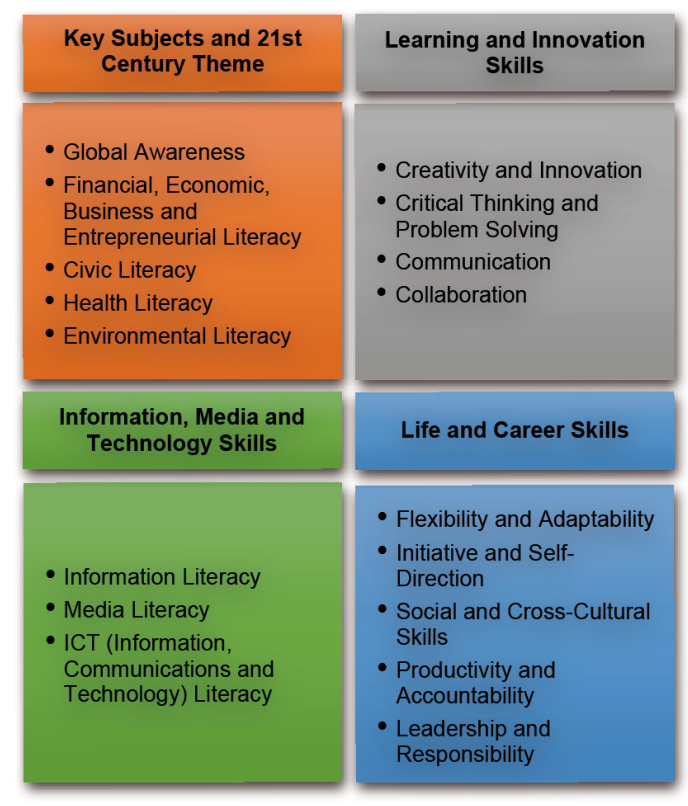

Fig. 1. Framework for 21 st-century Learning

It is really important to acquire 21 st-century skills including computational thinking [22]. According to literature, there is a lack of research on computational thinking in the context of robotic applications in North Cyprus. Computational thinking and robotic applications are closely related with each other [2]. Coding education and robotic applications in order to objectify coding education might be effective for teaching 21 st-century skills to students in North Cyprus.

\section{Problem Statement}

It is observed that coding education and robotic applications are integrated or being integrated into education systems of countries for the students at early ages throughout the world. In this context, the question of "What is the importance of coding edu- 
Paper-Importance of Coding Education and Robotic Applications For Achieving 21st-Century Skills in North Cyprus

cation and robotic applications for achieving 21st-century skills in North Cyprus?" constitutes the basic problem of the present study.

Answers to the following questions were sought in this study:

1. What are coding education and robotic applications?

2. What are the activities of universities in North Cyprus related with coding education and robotic applications?

3. What is the importance of coding education and robotic applications for North $\mathrm{Cy}-$ prus?

\section{Aim of the Study}

Aim of the study is to reveal the importance of coding education and robotic applications for achieving 21 st-century skills in North Cyprus. In line with this aim, literature review related with algorithm, programming, coding, computational thinking skills and robotic applications was conducted in order to reveal the current situation in North Cyprus. Especially, studies on robotic applications of universities in North Cyprus were examined and cooperation between Turkey and North Cyprus was emphasized. Lastly, barriers for being productive to achieve robotic applications were mentioned and relevant conclusion and recommendations were provided.

\section{Method}

This is a descriptive study based on literature review in order to reveal the current situation. Obtained data were evaluated by the researcher and interpreted based on a descriptive approach [9].

\subsection{Coding Education and Robotic Applications}

Coding education is the basis of robotic applications and programming skills constitute the basis of coding. In addition, algorithm is the basis of programming. Problem-solving skills constitute the basis of all of these mentioned skills.

Especially, being unable to acquire competences of problem-solving approaches and designing solutions effectively makes learning programming skills a difficult approach [33]. In recent years, it has become lively again through visual programming languages such as Alice code, code.ogr and Scratch [19]. It is possible to make computer programming easier and clearer for everyone through these applications [36, 17]. At this point, computational thinking arise as having essential knowledge, skills and attitudes for using computers as production tool in solving problems of daily life [15]. Computational thinking is a method for understanding human behaviors through emphasizing problem-solving, designing systems and basic concepts of computer science [25].

Furthermore, algorithmic thinking skills are important in acquiring problemsolving skills. Algorithmic thinking includes skills for understanding, applying, eval- 
Paper-Importance of Coding Education and Robotic Applications For Achieving 21st-Century Skills in North Cyprus

uating and producing algorithms [8]. Algorithm was invented by Ebu Abdullah Muhammed Ibn Musa el Harezmi who is a Muslim mathematician; not by a Western scientist [23].

In a research in which the effect of programming on the development of mathematical and computational thinking was examined, it was figured out that programming education is effective for teaching mathematics, developing problem-solving strategies and for collaborative, systematic and creative thinking [38].

Many operations and concepts remain as discrete when teaching programming language and students experience difficulties in objectifying knowledge. Robotic applications might be an appropriate approach for making this process concrete [21]. Robotic applications require coding education. In Table 1, some skills, application and robotic application tools related with coding education which can be used in school levels are demonstrated [3].

Table 1. Some Skills, Software And Robotic Application Tools Which Can Be Used In Coding Education

\begin{tabular}{|c|c|c|c|}
\hline School Level & Skills & Software & $\begin{array}{l}\text { Robotic Applica- } \\
\text { tion Tools }\end{array}$ \\
\hline Pre-school & $\begin{array}{l}\text { Putting in order, separating } \\
\text { into little pieces, giving order }\end{array}$ & $\begin{array}{l}\text { Scratch JR, Code.org, the first two } \\
\text { periods of Kodable, The foos }\end{array}$ & BeeBots, KIBO \\
\hline Primary School & $\begin{array}{l}\text { Using blog-based program- } \\
\text { ming tools, adding various } \\
\text { orders into programs }\end{array}$ & $\begin{array}{l}\text { Scratch JR, Code.org, scratch, koda- } \\
\text { ble and play code monkey }\end{array}$ & $\begin{array}{l}\text { Sphero, Dash \& } \\
\text { Dot, LEGO WeDo }\end{array}$ \\
\hline $\begin{array}{l}\text { Secondary } \\
\text { School }\end{array}$ & $\begin{array}{l}\text { Using blog-based program- } \\
\text { ming tools, adding various } \\
\text { orders into advanced level of } \\
\text { programs }\end{array}$ & $\begin{array}{l}\text { Scratch, robots which can be pro- } \\
\text { grammed with scratch, AppInventor, } \\
\text { Kodu Game Lab, Flip Boom Classic, } \\
\text { Crazytalk }\end{array}$ & Lego Mindstorms \\
\hline High School & $\begin{array}{l}\text { Using text-based program- } \\
\text { ming tools, Programming for } \\
\text { needs of real life }\end{array}$ & $\begin{array}{l}\text { Making games with Kodu Game Lab } \\
\text { and Unity, } \\
\text { Making mobile application with App } \\
\text { Inventor, } \\
\text { Making LabView application with } \\
\text { robotics, Making iOS application } \\
\text { with Swift, making desktop applica- } \\
\text { tion with C\# or web application with } \\
\text { Php or Asp.Net }\end{array}$ & $\begin{array}{l}\text { Ardunio, Raspber- } \\
\text { ry Pi... }\end{array}$ \\
\hline
\end{tabular}

In the environments mentioned in Table 1, primary goal is to develop learning outputs and increase student motivation through using as a tool which enables 21 stcentury skills rather than teaching coding itself [28].

Technological innovation named as "Robotic" has been integrated with various disciplines. It has also become an important part of especially science, technology and engineering education process [10].

Robot as a word has been derived from "robota" which means compulsory labor of slaves in old Czech and today's Slovak languages [18]. Today, robots are defined as self-controlled and programmable devices including electronic and mechanic departments [1]. 
Paper-Importance of Coding Education and Robotic Applications For Achieving 21st-Century Skills in North Cyprus

Studies on integrating coding education into curriculum as part of "FATIH" project applied in Turkey are being conducted and robotic applications are being discussed [40]. Educational, political and social developments occurred in Turkey are also reflected in North Cyprus since cultures of Turkish Cypriot and Turkish students are close to each other and there are strong relations between two countries [11].

Cloud computing, social network, increased mobility, increase in commercial values of open-source coded software are the most remarkable issues in North Cyprus and they increase the demand for information sector. "Informatics Island" vision is being conducted in the country and there are five basic targets included in this vision:

- Taking an active role in informatics world,

- Providing solutions for human-resource problem in informatics world with qualified human power through benefitting from universities in North Cyprus,

- Converting regional research centers into central informatics laboratory,

- Achieving technology transfer through enabling leading producer companies of the world in informatics to invest in our country, and

- Undertaking "Informatics Island" role through providing product and services to new technologies. In order to achieve these targets, Information Technologies Communication Institution, continues to work for the country. However, there should be more emphasis on coding education and robotic applications. In addition, universities in North Cyprus take an active role in achieving these targets [7].

\subsection{Activities of Some Universities in North Cyprus}

In parallel with "Informatics Island" vision, some universities in North Cyprus have developed robotic applications and tools.

\section{Near East University (NEU)1}

- In Near East Primary School, coding education is given as part of educational activities one hour a week on code.org website since 1st year of primary school. In addition, necessary materials and iPad tablets have been brought this year in order to give robotic education through LEGO WeDo and studies for program development towards robotic education have started.

- "Applied Artificial Intelligence Research Center" in 2011, "Robotics" research team in 2008 and "NEUIslenders" robot football team in 2010 were established in NEU. Education is given on computer technologies and programming artificial intelligence systems, control systems, softcomputing, signal operation and algorithm in the center. NEUIslenders is the first and only team in North Cyprus which deserved to participate in RoboCup Robotic Football World Cup. International RoboCup Competition and Conference is one of the biggest robotic organizations of the world [35].

- NEU Hospital provides surgery services with robot. Robotic surgery system which is at surgical console shortens the treatment duration of patients.

\footnotetext{
${ }^{1}$ https://neu.edu.tr/
} 
- NEU Educational Sciences Faculty has conducted the first and only experimental study in North Cyprus for 9th grade students from secondary education. In the study, Scratch education was given during an academic term and it was figured out that students' achievement scores increased and students reported positive views towards scratch program [39].

\section{Cyprus International University (CIU)2}

- Students from the department of CIU Electrical and Electronic Engineering designed light-sensitive robots which follow line, solve labyrinth and engage in sumo wrestling. "Robot Which Follows Line and Light-Sensitive Robot in Free Category as a Course Project" and "Sumo Robot and Robot Which Solves Labyrinth" projects were shown in a special platform as a part of CIU Robot 2013 Activities.

\section{Girne American University (GAU)3}

- Students are allowed to practice in Mechatronics lab established in GAU, automation and robot systems and courses given in engineering sciences. Students are reinforced by watching, trying and experiencing their theoretical knowledge through PLC (Programmable Logic Circuit) experiment sets, mobile robots and industrial robot systems.

- "Monitoring Robot" device which can be remote controlled through internet network was developed based on WEB Application Controlled Monitoring Robot project developed by GAU Computer Engineering Department.

\section{European University of Lefke (LAU)4}

- Two "Leopard Ges Robot appropriate for NASA standards" were produced by teachers and students from the department of LAU Electronics and Communication Engineering Department. The eco-friendly robots were produced for defense and security, they use green energy and they are designed with a technology which can charge themselves on electromagnetic waves. Mechanisms of the robots are sensitive to moving objects and they have features including helping each other and recording audio/image through using different connections such as "Wifi", "GPRS" and "Bluetooth". Besides, they can move between humans, find their direction, send data instantly and record them.

Apart from these mentioned universities, there are no studies conducted in other universities in North Cyprus related with coding education and robotic applications or projects designed in private sector.

There is a need to increase coding and robotic applications since universities are effective in scientific and educational areas. Universities need to prepare more environments and motivate students. North Cyprus government must provide support to

\footnotetext{
${ }^{2}$ http://www.ciu.edu.tr/en

$3 \overline{\mathrm{http}: / / \text { www.gau.edu.tr/en} /}$

$4 \underline{\text { http://www.eul.edu.tr/en/ }}$
} 
Paper-Importance of Coding Education and Robotic Applications For Achieving 21st-Century Skills in North Cyprus

universities. Coding and robotic education have to be started and integrated in preschool, primary school and high school levels.

\section{$5 \quad$ Method Conclusion and Recommendations}

Recent technological developments require individuals to tend towards consumption rather than production. Coding education is given beginning from early childhood in many countries in the world [6,37].

15 EU countries have already integrated coding in their school curriculum. These are: Austria, Bulgaria, the Czech Republic, Denmark, Estonia, France, Hungary, Ireland, Lithuania, Malta, Spain, Poland, Portugal, Slovakia and the England. Among them, France and Spain have integrated coding only recently (in 2014-2015). Finland announced it will integrate coding in its curriculum in 2016. And Belgium (Flanders) is currently debating whether to integrate coding at school. 9 EU countries already integrate or will integrate coding at primary school level soon. Already integrate: Estonia, France, Spain, Slovakia, UK (England). Will integrate: Belgium (Flanders), Finland, Poland, Portugal. 12 EU countries already integrate or will integrate coding at upper secondary school level in general education. Austria, Bulgaria, Denmark, Estonia, France, Hungary, Lithuania, Malta, Poland, Slovakia, Spain and the United Kingdom (England) $[12,14,16]$. In Turkey, Information Technologies and Software course are included in $5^{\text {th }}, 6^{\text {th }}, 7^{\text {th }}$ and $8^{\text {th }}$ grades as elective course based on the curriculum published in 2012 .

In North Cyprus, it is observed that there is still insufficient importance given to coding education and robotic applications. It is revealed that there are effective robotic studies as a result of institutional efforts by universities. However, there is no attempt to integrate coding education into primary, secondary and university education programs and there is a little number of academic research related with coding education and robotic applications. On the other hand, many countries have included or are including coding education into curriculum.

Domestic market habit, being non-institutionalised, focusing on short dated targets, lack of projects in informatics sector and unable to receive investment/promotion support are the most remarkable inhibitive factors in terms of informatics in North Cyprus. Legal basis of Cyprus local-origin companies is not secure in international platforms because of political problems in the country. There is burn-out and hopelessness among companies and individuals in the sector because of on-going isolations in the country. In addition, since there is no opportunity to conduct comprehensive projects and there is uncertainty in the sector; products which are short dated and require less investment are more preferred by companies [5].

Companies, universities and government of North Cyprus need to make investments and serious attempts for coding education and robotic applications in order to inform and educate next generation. New professions will emerge in the near future and many existing professions will not be needed. Children will play an active role in North Cyprus in terms of being a society which produces products with high technology. Therefore, it is crucial to teach 21 st-century skills to children [16]. 
Paper-Importance of Coding Education and Robotic Applications For Achieving 21st-Century Skills in North Cyprus

In this context, recommendations for achieving coding education and robotic applications which have received great attention throughout the world in North Cyprus as well are provided below:

- In spite of all difficulties, North Cyprus tries to reach global market and increase income. This leads to a serious need for Central Government to direct and for Local Governments, Non-governmental organizations, Private Sector and Universities to undertake the leadership role. Since Informatics Sector is related with the development of the economy, Ministry of Economy and Energy and The Ministry of Public Works and Transport need to work together and employ through undertaking leadership role in informatics and development issues.

- Investment, cooperation and coordination are needed for constituting a competitive informatics sector. Attempts which enable university-industry-sector cooperation especially in the field of informatics should be supported. Technopark and innovation laws which are still waiting should be immediately completed since this is an inevitable necessity for active and competitive sector.

- Contents of educational programs for coding education and robotic applications should be developed appropriate for new generation technology and applied based on a certain program beginning from early childhood.

- National education program should be applicable for all teachers and essential materials and tools should be determined and provided in order to apply the program.

- Needs of teachers in terms of quantity and quality should be determined and the number of teachers who have basic knowledge and skills should be increased.

- Information Technologies Communication Institution (BTHK), companies, universities and government should work together cooperatively in order to provide opportunities for professional development about coding education and robotic applications topics and overcome the deficiencies in terms of in-service training.

- Academicians who are specialized in computer science field and related departments need to conduct scientific studies on coding education and robotic applications.

\section{$6 \quad$ References}

1. Arora, M., "Design and Development of Friction Compesator Algorithm For One Link Robot", Thesis submitted in the partial fulfilment of the requirement for the award of degree of Master of Engineering in Electronics Instrumentation and Control Engineering. Thapar University, Patiala, 2008.

2. Barut, E., Tugtekin, U., \& Kuzu, A., "An Overview of Computational Thinking Skills with Robotic Applications", The 3rd International Conference on New Trends in Education (ICNTE), 2016.

3. Berksoy, I., Sozcu, F., O., Armagan, E., \& Arslan, A., "Analysis of Studies on Scratch Program in Algorithm and Programming Education", XVIIIth Academic Informatics Conference (INETD), 30 January - 5 February 2016, Adnan Menderes Üniversity, Aydin, 2016. 
Paper-Importance of Coding Education and Robotic Applications For Achieving 21st-Century Skills in North Cyprus

4. Bers, M. U., Flannery, L., Kazakoff, E. R., \& Sullivan, A., "Computational thinking and tinkering: Exploration of an early childhood robotics curriculum". Computers \& Education, 72145-157,2014. http://doi.org/10.1016/j.compedu.2013.10.020

5. Bilisim Teknolojileri ve Yazilim Dersi Programi (2015), "Talim Terbiye Kurulu Baskanligi", Accessed November 17, 2016 Ankara http://ttkb.meb.gov.tr/

6. Demirer, V., \& Sak, N., "Programming Education and New Approaches Around The World and in Turkey", Journal of Eğitimde Kuram ve Uygulama, 2016, 12(3), 521-546. Accessed November 17, 2016. http://eku.comu.edu.tr/article/view/5000156188/5000164 $\underline{272}$

7. Information Technologies Communication Institution (BTHK), (2016). "Raporlar ve Yayinlar" Accessed November 10, 2016. http://www.bthk.org/resmi-istatistikler-veyayinlar/

8. Brown, W. (2015). Introduction to Algorithmic Thinking. Accessed November 17, 2016. https://docs.google.com/document/d/1MyFYez2SQvsfq7r1StE2kxZyX-Um52Zuc1C4HGv UdtQ/edit

9. Buyukozturk, S., Cokluk, O. \& Koklu, N., "The statistics for the social sciences" (6th Edition). Ankara: Pegem Academy, 2010.

10. Cameron, R. G., "Mindstorms Robolab: Developing science concepts during a problem based learning club, The Master thesis, Department of Curriculum, Teaching and Learning, The University of Toronto, Canada, 2005.

11. Cavus, N., \& Kanbul, S., "Designation of Web 2.0 tools expected by the students on technology-based learning environment" Procedia - Social and Behavioral Sciences, 2(2), 5824-5829, 2010. http://doi.org/10.1016/j.sbspro.2010.03.950

12. Computing our future. Computer programming and coding - Priorities, school curricula and initiatives across Europe. European Schoolnet (2014). Accessed November 17, 2016. http://www.eun.org/c/document library/get file?uuid=521cb928-6ec4-4a86-b522-9d8fd5 cf60ce\&groupId $=43887$

13. Cavus, N., \& Uzunboylu, H., "Improving critical thinking skills in mobile learning" Procedia - Social and Behavioral Sciences, 1(1), 434-438, 2009. http://doi.org/10.1016/j.sbspro.2009.01.078

14. Coding - the 21st-century skill (2016). Accessed November 17, 2016. https://ec.europa.eu/digital-single-market/coding-21st-century-skill

15. Curzon, P. (2015). Computational Thinking: Searching to Speak. Accessed November 17, 2016. https://cs4fndownloads.files.wordpress.com/2016/02/searchingtospeak-booklet.pdf

16. EU Code Week (2015). Accessed November 17, 2016 http://en.euractiv.eu/wpcontent/uploads/sites/2/special-report/euractiv special report - eu code week 2015$1 . \mathrm{pdf}$

17. Flanagan, S. (2015). Introduce Programming in a Fun, Creative Way. "Teach Digital Citizenship and Literacy" Accessed November 14, 2016. http://scratched.gse.harvard.edu/sites/default/files/tech directions article - january 2015. pdf

18. Horakowa, J. \& Kelemen, J., “Čapek, Turing, von Neumann, and the 20th Century Evolution of the Concept of Machine" International Conference in Memoriam John von Neumann, John von Neumann Computer Society, Budapeste, 2003.

19. Kalelioglu, F. \& Gulbahar, Y., "The Effects of Teaching Programming via Scratch on Problem Solving Skills" Informatics in Education, Vol. 13, No. 1, 33-50, 2014.

20. Karahoca, D., Karahoca, A. and Kurnaz, A.. "Analyzing Communication Dimensions in a Ubiquitous Learning Environment”. Journal of Universal Computer Science, 2016 Jan 1;22(1):124-45. 
Paper-Importance of Coding Education and Robotic Applications For Achieving 21st-Century Skills in North Cyprus

21. Karahoca, D., Karahoca, A., \& Uzunboylu, H., "Robotics teaching in primary school education by project based learning for supporting science and technology courses" Procedia Computer Science, 3, 1425-1431. 2011. http://doi.org/10.1016/j.procs.2011.01.025

22. Keser, H., Uzunboylu, H., \& Ozdamli, F., "The trends in technology supported collaborative learning studies in 21st-century", World Journal on Educational Technology, 3(2), 2011. Accessed November 10, 2016. http://sproc.org/archives/index.php/wjet/article/ view/256

23. Kilan, N., K., (2001). "The Spirit of Computer : Algorithm - Algoritmics" Accessed November 17, 2016. http://www.baskent.edu.tr/ kkilan/courses/Makaleler/Bilgisayarin\%2 0cani/Bilgisayarin\%20Cani-Bildiri-07.doc

24. Koç, A., \& Boyuk, U., "Technology Based Learning in Science and Technology Education: Robotic Applications", Journal of Turkish Science Education. v.10, n.1, pp.139-155, 2013.

25. Korkmaz, O., Cakir, R., Ozden, M. Y., Oluk, A., \& Sarioglu, S., "Investigation of Individuals' Computational Thinking Skills in terms of Different Variables" Ondokuz Mayis University Journal of Faculty of Education, 34(2), 68-87, 2015. Accessed November 10, 2016. http://dergipark.ulakbim.gov.tr/omuefd/article/view/5000163470/5000149579

26. Licciardello, O., Mauceri, M., \& Marco, G., "Use of information and communication technologies improves healthy and unhealthy elderly people's quality of life - the key role of the training setting", World Journal on Educational Technology, 8(1), 32-40, 2016. http://dx.doi.org/10.18844/wjet.v8i1.499

27. Maldague, X., Kuimova, M., Burleigh, D., \& Skvortsova, S. Information and communication technologies in engineering education. Paper presented at the MATEC Web of Conferences, 79, 2016. doi:10.1051/matecconf/20167901044

28. Maloney, J., Resnick, M., Rusk, N., Silverman, B., \& Eastmond, E., "The Scratch Programming Language and Environment”, Trans. Comput. Educ., 10(4), 1-15, 2010. https://doi.org/10.1145/1868358.1868363

29. Monroy-Hernández, A., \& Resnick, M., "Empowering Kids to Create and Share Programmable Media" Interactions 15,2, (pp. 50-53), 2008. https://doi.org/10.1145/1340961.1340974

30. Partnership for 21st-century Skills (2007). "Framework for 21st-century Learning" Accessed July 20, 2016. http://www.p21.org/about-us/p21-framework

31. Perković, L. \& Settle, A., "Computational Thinking across the Curriculum: A Conceptual Framework", College of Computing and Digital Media Technical Report, 10-001, DePaul University, 2010.

32. Pillay, N. \& Jugoo, V., "An investigation into student characteristics affecting novice programming performance", ACM SIGCSE Bulletin 37: 107-110, 2005.

33. Pinto, A., \& Escudeiro, P., "The use of Scratch for the development of 21 st-century learning skills in ICT", In Information Systems and Technologies (CISTI), 9th Iberian Conference on (pp. 1-4), 2014.

34. Resnick, M., Kafai, Y., Maloney, J., Rusk, N., Burd, L., \& Silverman, B., “A Networked, Media-Rich Programming Environment to Enhance Technological Fluency at AfterSchool Centers in Economically-Disadvantaged Communities" Proposal to National Science Foundation, 2003.

35. RoboCup, (2016). "A Brief History of RoboCup" Accessed November 17, 2016. http://www.robocup.org/a brief history of robocup

36. Shin, S., Park, P., \& Bae, Y., "The Effects of an Information-Technology Gifted Program on Friendship Using Scratch Programming Language and Clutter", International Journal of Computer and Communication Engineering, 2 (3), 246, 2013. 
Paper-Importance of Coding Education and Robotic Applications For Achieving 21st-Century Skills in North Cyprus

37. Sayin, Z., \& Seferoğlu, S., S., "Coding education as a new 21 st-century skill and effect of coding on educational policies" Academic Informatics 2016, 3-5 February 2016, Adnan Menderes University, Aydin. November 17, 2016. http://ab.org.tr/ab16/ozet/258.html

38. Taylor, M., Harlow, A., \& Forret, M., "Using a computer programming environment and an interactive whiteboard to investigate some mathematical thinking", Procedia-Social and Behavioral Sciences, 8, 561-570, 2010. http://doi.org/10.1016/j.sbspro.2010.12.078

39. Tugun, V., "Evaluation of students' achievement, motivation, experience and views and flipped classroom model and coding education" Doctorate thesis. Near East University. Institute of Educational Sciences, Nicosia, North Cyprus, 2015.

40. YEGITEK, (2016). "Zihinden Makineye Bilgisayar Bilimleri ve Disiplinler Arasi Egitim Calistayi" Accessed November 10, 2016. http://yegitek.meb.gov.tr/www/zihindenmakineye-bilgisayar-bilimleri-ve-disiplinler-arasi-egitim-calistayi-yapildi/icerik/786

\section{$7 \quad$ Authors}

Sezer Kanbul is with the Department of Computer Education \& Instructional Technology, Near East University, P.O. Box: 99138, Nicosia, North Cyprus (e-mail: sezer.kanbul@neu.edu.tr).

Huseyin Uzunboylu is with the Department of Educational Curriculum and Instruction, Dean, Faculty of Ataturk Education, Near East University, P.O. Box: 99138, Nicosia, North Cyprus (e-mail: huseyin.uzunboylu@neu.edu.tr).

Submitted 02 August 2016. Published as resubmitted by the authors 10 October 2016. 